\title{
Investigations on Z-Source Based Three Level Inverter
}

\author{
Chinnapettai Ramalingam Balamurugan and Kumaravel Vijayalakshmi \\ Karpagam College of Engineering, Coimbatore, Tamil Nadu, India \\ crbalain2010@gmail.com
}

\begin{abstract}
This paper presents the new inverter topology based on combination of Z Source Inverters (ZSI) and Multi Level Inverters (MLI). The basic structure includes one DC voltage source, Z-network and multilevel inverter. MLI composed of four switches to generating three voltage levels. The proposed work eliminates the limitations of both voltage source inverter and current source inverter by replacing multilevel inverter. The presence of multilevel inverters provide high output voltages with low harmonics without the use of transformers. The $Z$ source concept can be applied to ac-dc, dc-ac, ac-ac and ac-dc power conversions. Z-source inverter can able to boost up the inverter Direct Current (DC) side voltage. This work observes the rms (Root Mean Square) output voltage and presence of THD (Total Harmonic Distortion) in the output waveform by simulating the $Z$ source multilevel inverter using MATLAB/simulink. The Z-source multilevel inverter is simulated by sinusoidal reference, TAR reference, THI reference and trapezoidal reference with various inductance $(L)$ and capacitance $(C)$ values. The $R M S$ voltage is controlled by varying the modulation index.
\end{abstract}

Keywords: IndexTerms - Z Source Inverter, Multilevel Inverter, THD, RMS, Reference Signals

\section{Introduction}

The Z-source inverter topology was developed in 2002 to overcome the problems of traditional inverters. $Z$ source inverter is used to reduce the line current harmonic, high reliability and improves the input power factor. The traditional $\mathrm{Z}$ source inverter consists of an impedance network having two inductors and two capacitors. The main circuit is coupled with the DC source using impedance network in $\mathrm{Z}$ source inverter. Z-source inverter used in both bucks and boost operations. Shoot through state of the ZSI determines the buck- boost feature to the inverter. The proposed work presents the features of Z-source multilevel inverter to eliminate the limitation of voltage source inverter and current source inverter by replacing multilevel inverter. Multilevel inverters are composed of a number of power electronics switching devices and DC voltage sources. Multilevel inverters increase the voltage levels in the output, provide higher quality of power in its output and reduce the harmonic contents. The Z-source multilevel inverter has the ability to buck-boost the voltage. Keith Corzine and Yakov Familiant in [1] discussed about a new cascaded multilevel inverter $\mathrm{H}$ bridge drive. This concept, as well as supplying each cell with a unique dc voltage, can result in a high number of dc voltage levels. Peng in [2] determined about functions of Z- Source inverter. It employs an impedance network to couple the main circuit with DC source. Z-source network composed of two inductors and two capacitors. The Z- source concept can be applied to ac-dc, dc-ac, ac-ac and dc-dc power conversions. The Z- source inverter can overcome the limitations of voltage source and current source inverters. Peng et al. in [3] discussed about $\mathrm{Z}$ source inverter system and control for Adjustable Speed Drives (ASD). The Z-

Received (November 11, 2016), Review Result (July 10, 2017), Accepted (August 18, 2017) 
source inverter ASD system used to reduce the inrush and harmonic current and provide ride-through during voltage sags without any additional circuits. Peng et al. in [4] arranged about Z-source inverter for motor drives. This paper presents Z-source inverter system and control for general purpose motor drives. ZSI employs a unique LC network in the DC link and a small capacitor on the AC side of the diode front end. By controlling shoot through duty cycle the $\mathrm{Z}$ source can produce any desired output $\mathrm{AC}$ voltage, even greater than the line voltage. It minimizes the motor ratings to deliver required power.

Peng et al. in [5] suggested about application of Z- source inverter for traction drive of fuel cell-Battery hybrid electric vehicles. Z-source inverter utilizes an exclusive Z-source network to link the main inverter circuit to FC. Miaosen Shen and Fang Zheng Peng in [6] proposed about operating modes and characteristics of Z-source inverter with small inductance or low power factor. This paper also analyzed the Z-source inverter performance under maximum boost control with third harmonic injection. Rajesh Gupta et al. in [7] suggested about switching characterization of cascaded multilevel inverter controlled system. Yu Tang et al. in [8] introduced about improved Z-source inverter with reduced Z -source capacitor voltage stress. Compared to traditional Z-source inverter, it can reduce the capacitor voltage stress. A soft start strategy is also proposed to avoid the inrush surge. Mariusz Malinowski et al. in [9] made a survey on cascaded multilevel inverter. This paper has reviewed the recent trends and applications of this inverters. Dong Cao et al. in [10] familiarize the low cost semi-Z-source inverter for single phase photovoltaic system. Different from traditional Z- source inverter with an extra shoot through state two achieve the boost function, the two switches of semi $\mathrm{Z}$ source inverter are controlled. Input DC source and output Alternative Current (AC) voltage share the common ground to eliminate the leakage current caused by (PV) Photo Voltaic panel.

Banaei et al. in [11] proposed about $Z$-source based multilevel inverter. The basic unit based on cascaded units and $\mathrm{H}$ bridge unit. A Dynamic voltage restorer (DVR) is controlled voltage injected between the supply voltage and load. In this paper modeling and simulation of a DVR with novel multilevel based Z- source inverter have been presented.

Nguyen et al. in [12] made a survey about improved Trans-Z- source inverter with continuous input current and boost inversion capability. The Trans Z-source inverter topology provides high boost voltage inversion capability, resonance suppression and continuous input current. Sangeeta DebBarman et al. in [13] proposed different types of PWM techniques analysis for $\mathrm{Z}$ source inverter. This paper proposed a Simple Boost Control (SBC) and Maximum Bosst Control (MBC) as well as its implementation with third harmonic and triplen harmonic injection. Mohit Tyagiet al. in [14]described about the $\mathrm{Z}$ source is a novel power conversion topology that can buck and boost the given input voltage using passive components. Ramalingam seyezhai in [15] proposed a phase shifted sinusoidal pulse width modulation with simple boost control, maximum boost control and constant boost control. Fengjiang et al. in [16] considered about calculation of switching loss and also current total harmonic distortion of cascaded multilevel inverter. An European efficiency enhancement scheme with adjusting carrier frequency in real time is proposed. Different from the exiting efficiency improvement schemes, the aim of this paper is the issue of European efficiency enhancement.

Liu et al. in [17] composed of Quasi Z-Source Modular Cascaded Converter (QZSMCC) for high power photovoltaic system. The Quasi Z source MCC PV system accomplishes the modular topology, at scalable voltage and power with high reliability. The QZS-MMC supported the high voltage (HV) application of PV through a series connection of QZS-half bridge (HB) systems. Zhang et al. in [18] planned about Maximum boost control of diode assisted buck- boost voltage source inverter with low switching frequency. In order to maximize the efficiency and increase the gain this paper proposes a Pulse Width Modulation (PWM) strategy. The PWM strategy is proposed to achieve the instantaneous maximum utilization of intermediate de link voltage. Sarala in 
[19] detailed about improved Z-source inverter fed induction motor for wind applications. The operating modes of Z-source induction motor is studied using this paper.

Gnana Sambandam et al. in [20] make a design of optimal low switching frequency pulse width modulation of current fed five level inverters for solar integration. Current fed five level converters have several advantages in terms of high power capability, transformer less operation and short circuit protection. This paper implements a modified synchronous optimal pulse width modulation technique for five level current fed inverters at low device switching frequency. In large solar power plants low device switching frequency is needed in order to achieve the efficient operation of inverter. Mahmoudi et al. in [21] schemed about control of a filter less Z-source inverter. This Z-source inverter does not require filter at the output side to generate smooth $\mathrm{AC}$ voltage. It also provides control strategy based on the concept of Model Predictive Control (MPC). This system can generate various range of frequency voltages. The inverter has fast dynamic response when operated by MPC method. Trabelsi et al. in [22] states about Quasi Z-source based multilevel inverter. This paper proposes $1 \mathrm{MW}$ grid-tie photovoltaic system. It allows boosting the voltage while solving the imbalance problem DC link voltage in cascaded $\mathrm{H}$ bridge inverter. Multilevel output voltage waveform is produced using enhanced phase shift pulse width modulation. The effective control scheme is proposed to achieve low Total Harmonic Distortion and unity power factor. Malathy and Ramaprabha in [23] designed about new single phase multilevel inverter with less number of switches. Multilevel inverters are prepared over traditional inverter as the quality of output voltage improved with higher levels. The proposed topology in this paper utilizes lesser number of components to generate specific number of output voltage. Viju Nair et al. in [24] schemed about generation of higher number of voltage level by stacking inverters of lower multilevel structure. An important feature of stacked structure is the use of low voltage devices while attaining higher number of levels. C.R.Balamurugan et al. in [25] designed a single phase symmetrical multilevel inverter for various loads. This proposed topology has less number of switches than the conventional one.

\section{Z source Inverter}

Figure 1 represents the conventional $\mathrm{Z}$ source inverter. In this figure an impedance network having two capacitors and two inductors, which are arranged in $\mathrm{X}$ shape. That connects the maincircuit with the DC supply.

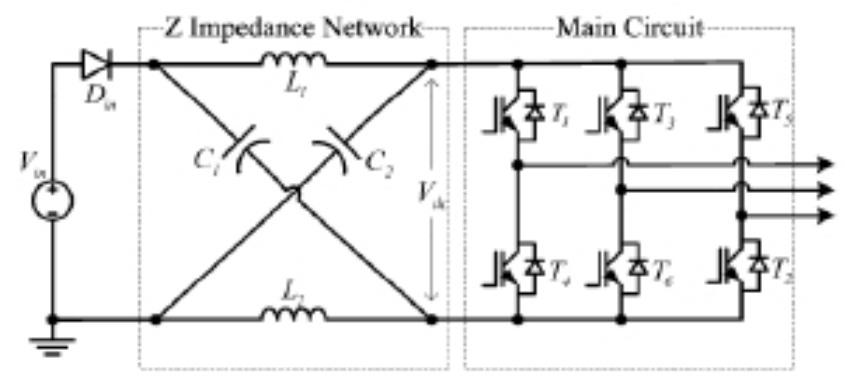

Figure 1. Conventional Z-source Inverter

A. Types of states

1. Shoot through state

2. Non-shoot through state

B. B. Shoot through state

Figure 2 shows the shoot through state of the conventional $\mathrm{Z}$ source inverter. In three phase $\mathrm{Z}$ source inverter, there are nine switching states but in the voltage source inverter, there are eight switching states. The extra state in the $\mathrm{Z}$ source inverter is known as shoot through state. During this state, the diode connected in series with the DC source is 
reverse biased and disconnect the supply from the impedance network. So the inverter DC side voltage is zero.

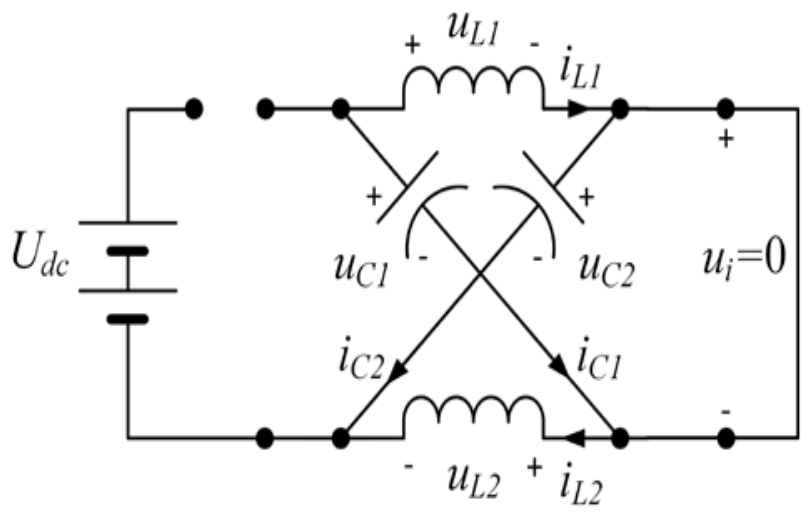

Figure 2. Shoot through State

C. Non -shoot through state

Figure 3 displays Non-shoot through state of the conventional $\mathrm{Z}$ source inverter. During this state the diode is forward biased and the impedance network is connected with the DC source. The capacitors in the impedance network are being charged and the inductors act as an additional current source. So the inverter side voltage is boosted.

$$
\begin{aligned}
& i_{1}=\frac{d_{1}}{d} \\
& y_{2}=I_{2} \frac{d_{2}}{d}
\end{aligned}
$$

$\mathrm{i}_{\mathrm{C} 1 \text { - Capacitor current }}$

$\mathrm{u}_{\mathrm{L} 2}$ - Inductor voltage

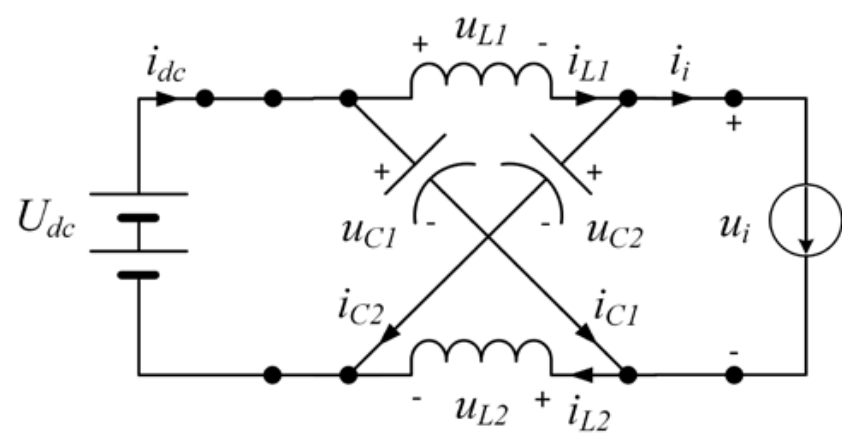

Figure 3. Non Shoot through State

\section{Multilevel Inverter}

The main feature of a MLI is its ability to reduce the voltage stress on each power device due to the utilization of multiple DC sources. Figure 4 shows the cascaded multilevel inverter.

The function of a MLI is to synthesize a desired AC output voltage from several DC voltage sources with low distortion.

The cascaded MLI can be used as compensator in power system because it does not present unbalance problem in DC source. Figure 4 shows a single phase five level configuration. The output voltage is equal to the summation of the output voltages of the respective modules.

$$
\mathrm{V}_{0}=\mathrm{V}_{11}+\mathrm{V}_{12}
$$


$\mathrm{V}_{11}$ - output voltage of module 1

$\mathrm{V}_{12}$ - output voltage of module 2

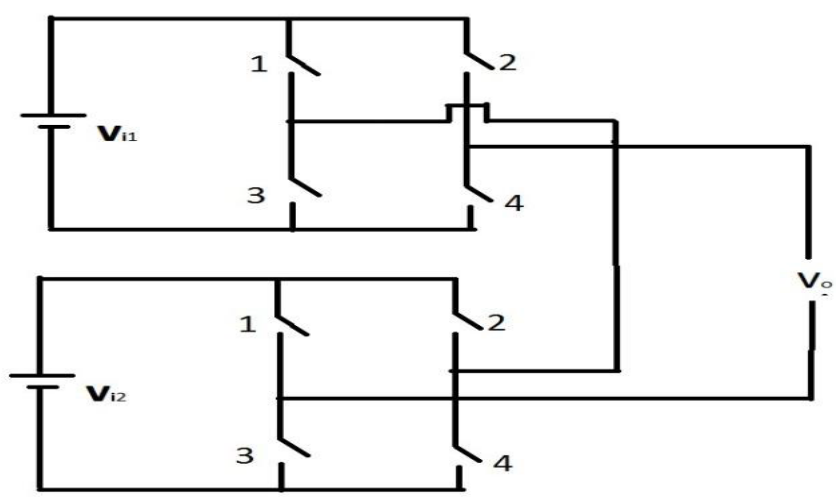

Figure 4. Cascaded Multilevel Inverter

Each module has its own DC source and consists of four power devices. Each module can generate three level of output $+\mathrm{V}_{\mathrm{dc}}, 0$ and $-\mathrm{V}_{\mathrm{dc}}$.

Table 1 shows the output voltage with the corresponding switching states of upper power devices of two modules of the five level inverter. The voltage across each device is $\mathrm{V}_{\mathrm{dc}}$.

Table 1. Switch States and Voltage Levels of Five Level Cascaded Inverters

\begin{tabular}{|l|l|l|l|l|}
\hline $\mathrm{S}_{11}$ & $\mathrm{~S}_{12}$ & $\mathrm{~S}_{12}$ & $\mathrm{~S}_{22}$ & Output $\left(\mathrm{V}_{0}\right)$ \\
\hline 1 & 0 & 1 & 0 & $+2 \mathrm{~V}_{\mathrm{dc}}$ \\
\hline 1 & 0 & 0 & 0 & $+\mathrm{V}_{\mathrm{dc}}$ \\
\hline 1 & 0 & 1 & 1 & $+\mathrm{V}_{\mathrm{dc}}$ \\
\hline 0 & 1 & 1 & 0 & $+\mathrm{V}_{\mathrm{dc}}$ \\
\hline 1 & 0 & 1 & 0 & $+\mathrm{V}_{\mathrm{dc}}$ \\
\hline 0 & 1 & 0 & 0 & 0 \\
\hline 1 & 0 & 1 & 1 & 0 \\
\hline 1 & 1 & 0 & 1 & 0 \\
\hline 0 & 0 & 1 & 0 & 0 \\
\hline 0 & 1 & 1 & 1 & 0 \\
\hline 1 & 1 & 0 & 0 & 0 \\
\hline 0 & 1 & 1 & 1 & $-\mathrm{V}_{\mathrm{dc}}$ \\
\hline 0 & 1 & 0 & 0 & $-\mathrm{V}_{\mathrm{dc}}$ \\
\hline 1 & 1 & 0 & 1 & $-\mathrm{V}_{\mathrm{dc}}$ \\
\hline 0 & 0 & 0 & 1 & $-\mathrm{V}_{\mathrm{dc}}$ \\
\hline 0 & 1 & 0 & 1 & $-2 \mathrm{~V}_{\mathrm{dc}}$ \\
\hline
\end{tabular}

\section{Z Source Based MLI}

Figure 5 shows the basic view of $Z$ source based multilevel inverter. The choice of multilevel inverter depends on the applications. This combination of $\mathrm{Z}$ source and multilevel inverter provides unique features. 


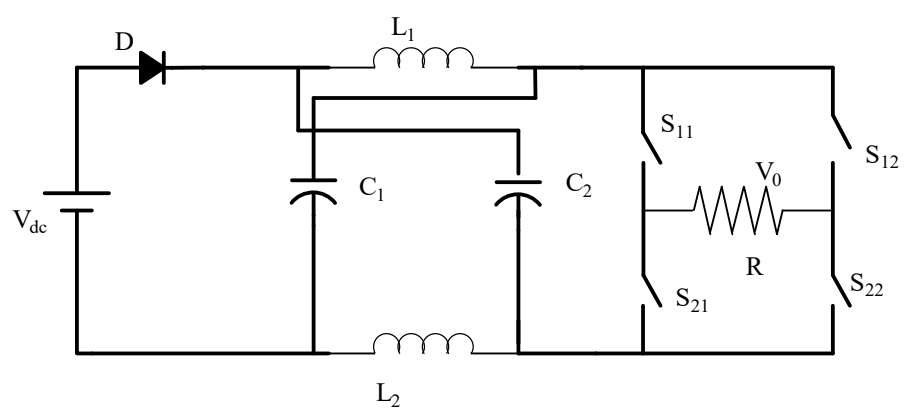

Figure 5. Basic Representation of Z Source Based MLI

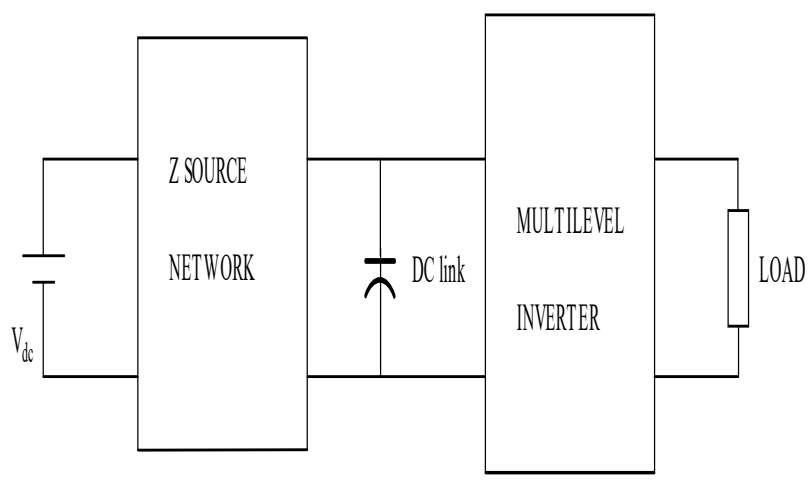

Figure 6. Power Circuit of Z Source Based Multilevel Inverter

$\mathrm{Z}$ source multilevel inverter composed of DC source, $\mathrm{Z}$ network and single $\mathrm{H}$ bride inverter. Figure 6 displays the power circuit of $Z$ source based multilevel inverter. Voltage stress problem in conventional $\mathrm{Z}$ source inverter is overcome by $\mathrm{Z}$ source multilevel inverter. Voltage source and current source inverters can either buck or boost the voltage but $\mathrm{Z}$ source based multilevel inverter can able to both buck and boost the given voltage.

The performance of $\mathrm{Z}$ source MLI has been analyzed and simulation results are presented using MATLAB/simulink. Presence of RMS voltage and THD in the output waveform is measured for various $\mathrm{L}$ and $\mathrm{C}$ values by using simulation.

Table 2. Chosen $L$ and $C$ values

\begin{tabular}{|l|l|l|}
\hline S.No & Inductance(H) & Capacitance(F) \\
\hline 1 & $3 \mathrm{mH}$ & $4700 \mu \mathrm{F}$ \\
\hline 2 & $3 \mathrm{mH}$ & $470 \mu \mathrm{F}$ \\
\hline 3 & $160 \mu \mathrm{H}$ & $1000 \mu \mathrm{F}$ \\
\hline 4 & $250 \mu \mathrm{H}$ & $500 \mu \mathrm{F}$ \\
\hline
\end{tabular}

In this paper Z source MLI is controlled by sinusoidal, TAR, THI, Step and Trapezoidal references. Variation of RMS output voltage and THD in the output voltage is observed for various modulation indices.

The modulation index controls the output voltage. The variation of modulation index from 0 to 1 varies the RMS output voltage. 


\section{Modulation Strategies for MLI}

There are many control methods employed for multilevel inverter. For controlling the output voltage, one of the methods is sinusoidal pulse width modulation method. In this method of modulation, several pulses per half cycle are used as in case of multiple pulse width modulation. Instead of maintaining the width of all pulses same as in the case of multiple pulse modulation, the width of each pulse is varied proportional to the amplitude of a sine wave. By comparing a sinusoidal reference signal with a carrier wave of frequency, the gating signals are generated. The area of each pulse corresponds approximately to the area under the sine wave between the adjacent midpoints of off periods on the gating signals. These strategies have more than one carrier option that can be triangular, inverted sine, saw tooth, etc. As far as the particular carrier signals are concerned there are multiple control freedom degree (CFD) including frequency, amplitude, phase of each carrier and offset between carriers. Different types of references are taken for modulation strategies of MLI such as sinusoidal, Third Injection (THI), Trapezoidal and stepped wave reference.

The multicarrier PWM methods have the following types.

1) phase disposition PWM strategy (PDPWM)

2) Phase opposition and disposition PWM strategy (PODPWM)

3) Alternative phase opposition and disposition PWM strategy (APODPWM)

4) Variable frequency PWM strategy (VFPWM)

The inverted sine carrier PWM method uses the conventional sinusoidal reference signal and inverted sine carriers. An inverted sine carrier helps to maximize the output voltage. The pulses are generated when the amplitude of modulating signals is greater than that of carrier signal. The inverted sine carrier PWM method has a better spectral quality and a higher fundamental component compared to the conventional sinusoidal PWM without pulse dropping. This ISCPWM method enhances the fundamental output voltage at low modulation index ranges. There is reduction of total harmonic distortion and switching losses.

In PDPWM strategy, all the carrier waves have same amplitude, frequency and phase. Since all carriers are selected with same phase. All carriers are having amplitude as 1. PODPWM method is same as PDPWM but carrier arrangement should be different. The carriers are equally divided into two groups based on positive/negative average levels. In this type the two groups are opposite in phase with each other while keeping in phase within the group. APODPWM method also same as PDPWM but one of the main different in APODPWM by comparing to PDPWM is that the alternate carriers are phase shifted by 180 degree with each other. In VFPWM method intermittent carrier having different frequency compared to lower and upper carrier.

In this paper phase opposition and disposition PWM technique is implemented using different types of references such as sinusoidal reference, TAR reference, THI reference, stepped reference and trapezoidal reference

\section{Simulation Results}

The present works simulate the $Z$-source MLI with filter using MATLAB/simulink. The Z-source MLI simulated by sinusoidal, THI, TAR, Trapezoidal and stepped references. The Power circuit of Z-source based MLI consists of R load with resistance of $10 \Omega$. The source voltage considered as $100 \mathrm{~V}$. The present LC filter has the values same as values present in impedance network. Increase in modulation index from 0 to 1 increase the peak value of output voltage.

By using simulation performance across multilevel inverter is observed. 


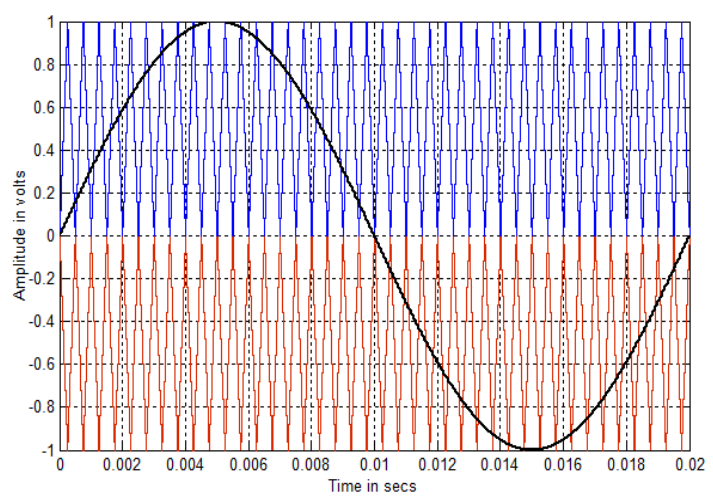

Figure 7. Carrier Arrangement with Sine Reference $\left(m_{a}=1, m_{f}=40\right)$

Figure 8 displays the carrier arrangement with THI reference. Fig 9 shows the carrier arrangement with trapezoidal reference. Figure 10 scenes the carrier arrangement with stepped reference. Figure 11 shows the carrier arrangement with TAR reference.

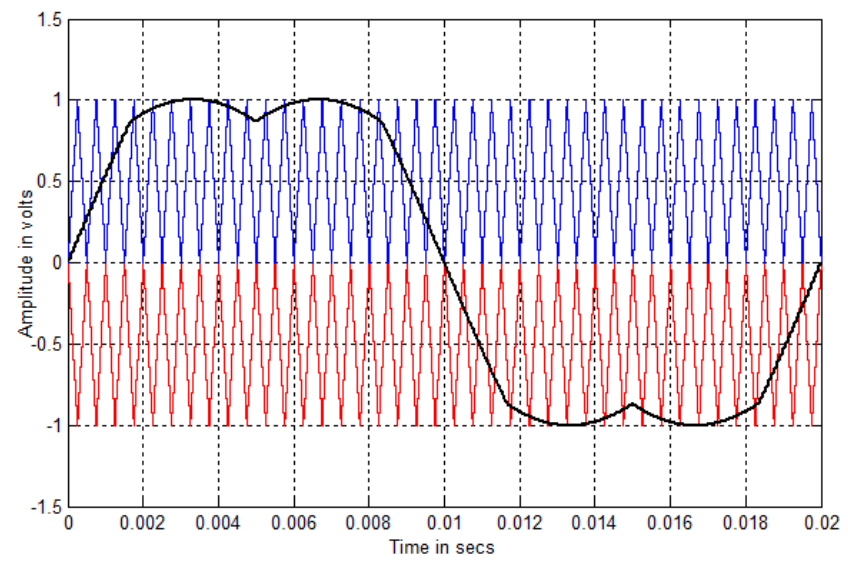

Figure 8. Carrier Arrangement with THI Reference $\left(m_{a}=2, m_{f}=40\right)$

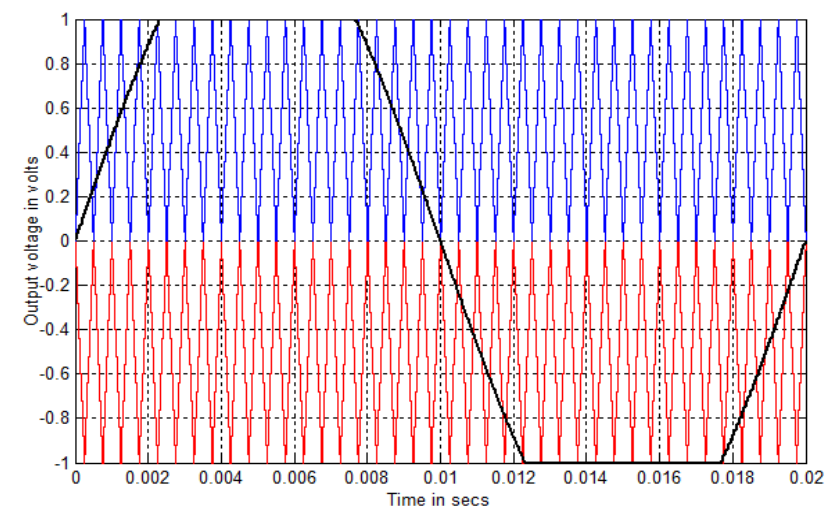

Figure 9. Carrier Arrangement with Trapezoidal Reference $\left(M_{a}=2, M_{f}=40\right)$ 


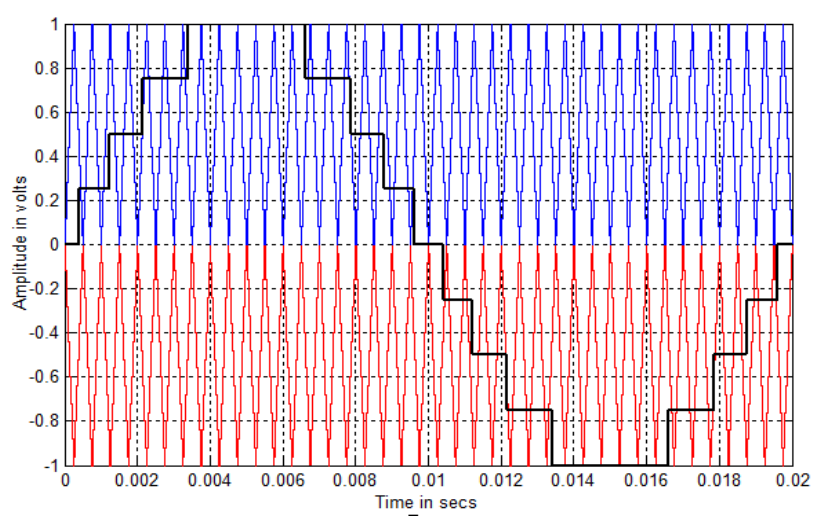

Figure 10. Carrier Arrangement with Stepped Reference $\left(M_{a}=1, M_{f}=40\right)$

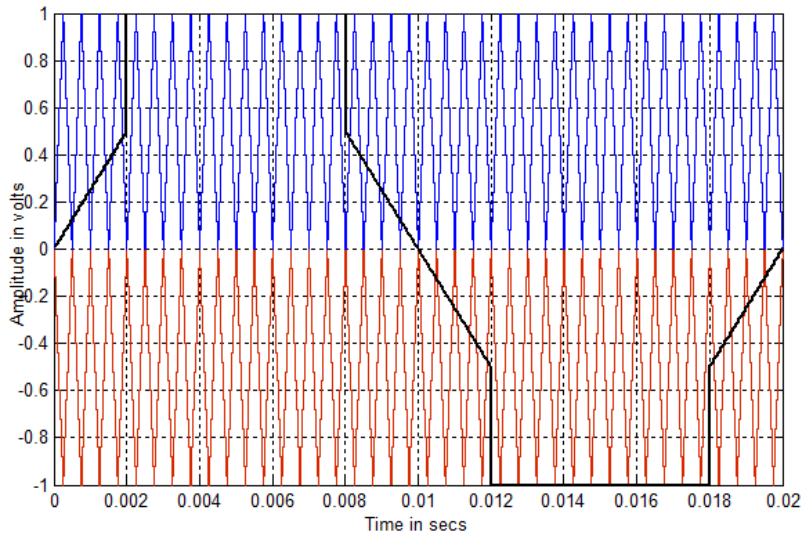

Figure 11. Carrier Arrangement with TAR Reference $\left(M_{a}=1, M_{f}=40\right)$

Output voltage across multilevel inverter with sinusoidal reference and sample FFT plot for $\mathrm{L}=3 \mathrm{mH}$ and $\mathrm{C}=4700 \mu \mathrm{F}$ is shown in Figure 12and 13.

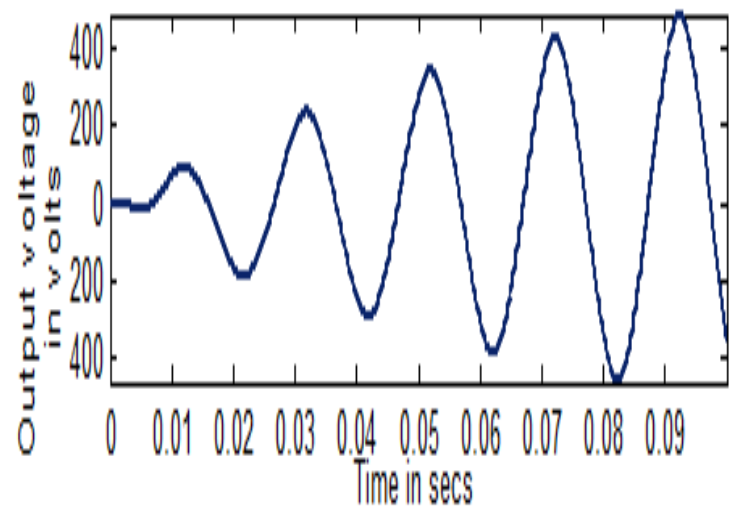

Figure 12. Output Voltage Across Multilevel Inverter 


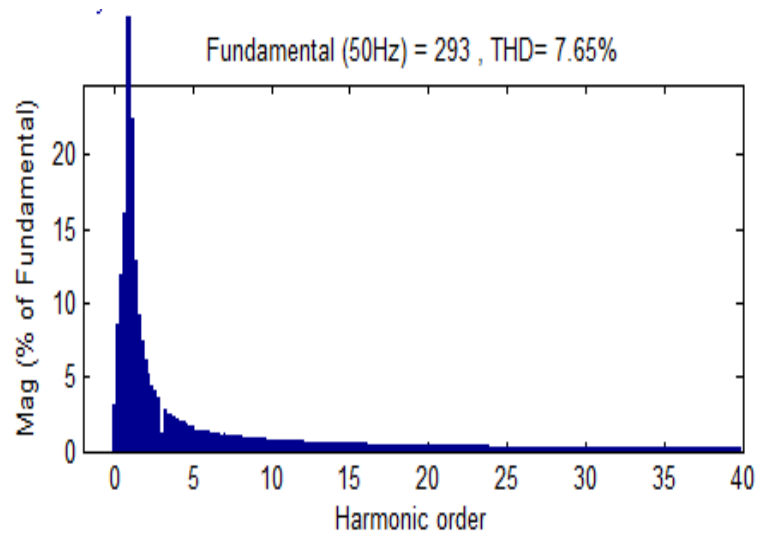

Figure 13. Sample FFT Plot

The following tables display the RMS output voltage and THD for various reference signals.

Table 3. Performance Measures Across Multilevel Inverter for $L=3 \mathrm{mH}$ and $C=4700 \mu F$

\begin{tabular}{|c|c|c|c|c|c|c|c|c|c|c|}
\hline \multicolumn{11}{|c|}{$\mathrm{L}=3 \mathrm{mH}, \mathrm{C}=4700 \mu \mathrm{F}$} \\
\hline \multirow[t]{2}{*}{$\begin{array}{l}\text { Modulation } \\
\text { Index }\end{array}$} & \multicolumn{2}{|c|}{$\begin{array}{l}\text { Sine } \\
\text { reference }\end{array}$} & \multicolumn{2}{|l|}{ Step } & \multicolumn{2}{|l|}{ TAR } & \multicolumn{2}{|l|}{ THI } & \multicolumn{2}{|c|}{ Trapezoidal } \\
\hline & $\begin{array}{l}\mathrm{V}_{\mathrm{rms}} \\
(\mathrm{V})\end{array}$ & $\begin{array}{l}\text { THD } \\
\text { in } \%\end{array}$ & $\begin{array}{l}\mathrm{V}_{\mathrm{rms}} \\
(\mathrm{V})\end{array}$ & $\begin{array}{l}\text { THD } \\
\text { in } \%\end{array}$ & $\begin{array}{l}\mathrm{V}_{\mathrm{rms}} \\
(\mathrm{V})\end{array}$ & $\begin{array}{l}\text { THD } \\
\text { in } \%\end{array}$ & $\begin{array}{l}\mathrm{V}_{\mathrm{rms}} \\
(\mathrm{V})\end{array}$ & $\begin{array}{l}\text { THD } \\
\text { in } \%\end{array}$ & $\begin{array}{l}V_{\text {rms }} \\
(V)\end{array}$ & $\begin{array}{l}\text { THD } \\
\text { in } \%\end{array}$ \\
\hline 1 & 207.3 & 7.65 & 210.1 & 7.78 & 236.5 & 10.6 & 245.7 & 11.2 & 245.9 & 11.27 \\
\hline 0.9 & 165.7 & 6.92 & 167.2 & 6.98 & 208.9 & 7.82 & 226.5 & 9.23 & 187.1 & 7.43 \\
\hline 0.8 & 126.6 & 7.39 & 126.3 & 7.48 & 161.5 & 6.87 & 184.6 & 7.54 & 93.61 & 7.58 \\
\hline 0.7 & 94.26 & 7.61 & 94.25 & 7.69 & 118.6 & 7.41 & 135 & 7.2 & 24.42 & 9.33 \\
\hline 0.6 & 62.73 & 7.88 & 62.24 & 7.95 & 83.27 & 7.63 & 90.64 & 7.62 & 6.57 & 13.93 \\
\hline
\end{tabular}

Table 4. Performance Measures Across Multilevel Inverter for $L=3 \mathrm{mH}$ and $\mathrm{C}=470 \mu \mathrm{F}$

\begin{tabular}{|c|c|c|c|c|c|c|c|c|c|c|}
\hline \multicolumn{11}{|c|}{$\mathrm{L}=3 \mathrm{mH}, \quad \mathrm{C}=470 \mu \mathrm{F}$} \\
\hline \multirow[t]{2}{*}{$\begin{array}{l}\text { Modulation } \\
\text { Index }\end{array}$} & \multicolumn{2}{|c|}{$\begin{array}{l}\text { Sine } \\
\text { reference }\end{array}$} & \multicolumn{2}{|l|}{ step } & \multicolumn{2}{|l|}{ TAR } & \multicolumn{2}{|l|}{ THI } & \multicolumn{2}{|c|}{ Trapezoidal } \\
\hline & $\begin{array}{l}\mathrm{V}_{\mathrm{rms}} \\
(\mathrm{V})\end{array}$ & $\begin{array}{l}\text { THD } \\
\text { in } \%\end{array}$ & $\begin{array}{l}\mathrm{V}_{\mathrm{rms}} \\
(\mathrm{V})\end{array}$ & $\begin{array}{l}\text { THD } \\
\text { in } \%\end{array}$ & $\begin{array}{l}\mathrm{V}_{\text {rms }} \\
(\mathrm{V})\end{array}$ & $\begin{array}{l}\text { THD } \\
\text { in } \%\end{array}$ & $\begin{array}{l}V_{\text {rms }} \\
(\mathrm{V})\end{array}$ & $\begin{array}{l}\text { THD } \\
\text { in } \%\end{array}$ & $\begin{array}{l}\mathrm{V}_{\mathrm{rms}} \\
(\mathrm{V})\end{array}$ & $\begin{array}{l}\text { THD } \\
\text { in } \%\end{array}$ \\
\hline 1 & 93.99 & 9.77 & 95.06 & 10.05 & 102.6 & 17.18 & 116.3 & 17.71 & 113 & 16.63 \\
\hline 0.9 & 85.25 & 10.57 & 86.35 & 11.87 & 94.26 & 12.72 & 109.6 & 19.65 & 92.29 & 14.58 \\
\hline 0.8 & 75.4 & 12.54 & 75.57 & 15.34 & 83.36 & 9.09 & 94.16 & 19.40 & 67.78 & 12.04 \\
\hline 0.7 & 66.54 & 14.54 & 66.71 & 16.24 & 72.12 & 10.08 & 78.85 & 17.20 & 40.96 & 10.88 \\
\hline 0.6 & 56.77 & 13.80 & 57.02 & 15.44 & 63.02 & 13.41 & 67.84 & 16.31 & 21.96 & 12.09 \\
\hline
\end{tabular}


Table 5. Performance Measures across Multilevel Inverter for $L=160 \mu \mathrm{H}$ and $C=1000 \mu \mathrm{F}$

\begin{tabular}{|l|l|l|l|l|l|l|l|l|l|l|}
\hline \multicolumn{2}{|l}{$\mathrm{L}=160 \mu \mathrm{H}, \mathrm{C}=1000 \mu \mathrm{F}$} \\
\hline $\begin{array}{l}\text { Modulation } \\
\text { Index }\end{array}$ & $\begin{array}{l}\text { Sine } \\
\text { reference }\end{array}$ & \multicolumn{2}{l|}{ step } & \multicolumn{2}{l|}{ TAR } & \multicolumn{2}{l|}{ THI } & \multicolumn{2}{l|}{ Trapezoidal } \\
\cline { 2 - 12 } & $\begin{array}{l}\mathrm{V}_{\text {rms }} \\
(\mathrm{V})\end{array}$ & $\begin{array}{l}\text { THD } \\
(\%)\end{array}$ & $\begin{array}{l}\mathrm{V}_{\text {rms }} \\
(\mathrm{V})\end{array}$ & $\begin{array}{l}\text { THD } \\
(\%)\end{array}$ & $\begin{array}{l}\mathrm{V}_{\text {rms }} \\
(\mathrm{V})\end{array}$ & $\begin{array}{l}\text { THD } \\
(\%)\end{array}$ & $\begin{array}{l}\mathrm{V}_{\text {rms }} \\
(\mathrm{V})\end{array}$ & $\begin{array}{l}\text { THD } \\
(\%)\end{array}$ & $\begin{array}{l}\mathrm{V}_{\text {rms }} \\
(\mathrm{V})\end{array}$ & $\begin{array}{l}\text { THD } \\
(\%)\end{array}$ \\
\hline 1 & 86.99 & 5.60 & 90.11 & 7.59 & 103.6 & 28.71 & 97.17 & 24.51 & 98.12 & 20.02 \\
0.9 & 84.68 & 3.81 & 87.37 & 6.90 & 96.83 & 26.95 & 92.18 & 24.63 & 90.17 & 19.48 \\
0.8 & 81.48 & 3.26 & 83.07 & 6.77 & 91.87 & 25.37 & 88.91 & 24.41 & 79.56 & 18.55 \\
0.7 & 77.15 & 3.51 & 78.01 & 6.93 & 85.27 & 23.59 & 84.65 & 23.89 & 58.43 & 18.69 \\
0.6 & 70.45 & 3.96 & 70.93 & 7.27 & 78.11 & 23.23 & 78.77 & 23.98 & 28.34 & 18.97 \\
\hline
\end{tabular}

Table 6. Performance Measures Across Multilevel Inverter for $L=250 \mu \mathrm{H}$ and $\mathrm{C}=500 \mu \mathrm{F}$

\begin{tabular}{|c|c|c|c|c|c|c|c|c|c|c|}
\hline \multicolumn{11}{|c|}{$\mathrm{L}=250 \mu \mathrm{H}, \mathrm{C}=500 \mu \mathrm{F}$} \\
\hline \multirow[t]{2}{*}{$\begin{array}{l}\text { Modulation } \\
\text { Index }\end{array}$} & \multicolumn{2}{|c|}{$\begin{array}{l}\text { Sine } \\
\text { reference }\end{array}$} & \multicolumn{2}{|l|}{ Step } & \multicolumn{2}{|l|}{ TAR } & \multicolumn{2}{|l|}{ THI } & \multicolumn{2}{|c|}{ Trapezoidal } \\
\hline & $\begin{array}{l}\mathrm{V}_{\mathrm{rms}} \\
(\mathrm{V})\end{array}$ & $\begin{array}{l}\text { THD } \\
(\%)\end{array}$ & $\begin{array}{l}\mathrm{V}_{\text {rms }} \\
(\mathrm{V})\end{array}$ & $\begin{array}{l}\text { THD } \\
(\%)\end{array}$ & $\begin{array}{l}\mathrm{V}_{\mathrm{rms}} \\
(\mathrm{V})\end{array}$ & $\begin{array}{l}\text { THD } \\
(\%)\end{array}$ & $\begin{array}{l}\mathrm{V}_{\text {rms }} \\
(\mathrm{V})\end{array}$ & $\begin{array}{l}\text { THD } \\
(\%)\end{array}$ & $\begin{array}{l}\mathrm{V}_{\mathrm{rms}} \\
(\mathrm{V})\end{array}$ & $\begin{array}{l}\text { THD } \\
(\%)\end{array}$ \\
\hline 1 & 78.63 & 7.16 & 82.18 & 10.61 & 92.97 & 19.84 & 90 & 27.05 & 89.98 & 22.79 \\
\hline 0.9 & 74.96 & 5.34 & 76.91 & 9.04 & 86.5 & 23.66 & 83.92 & 24.99 & 79.46 & 19.70 \\
\hline 0.8 & 70.93 & 4.36 & 72.16 & 8.73 & 80.15 & 27.07 & 79.03 & 24.29 & 68.73 & 17.97 \\
\hline 0.7 & 66.8 & 4.43 & 67.55 & 8.38 & 73.67 & 24.82 & 73.73 & 23.78 & 53.33 & 18.28 \\
\hline 0.6 & 61.98 & 4.95 & 62.43 & 8.72 & 67.72 & 23.58 & 68.69 & 23.77 & 27.49 & 18.87 \\
\hline
\end{tabular}

\section{Conclusion}

This paper has presented an impedance source inverter with multilevel inverter. The Zsource network employs a impedance network to couple the main circuit to the power source. This network provides unique features that cannot be provided in the traditional voltage source and current source inverter. The Z-source inverter can produce an output voltage that is greater than the ac input voltage by controlling boost factor. The presence of MLI increases the output voltage levels in the output and also reduces the harmonic contents in the output without the use of transformers. In this section, simulation is performed for proposed Z-source based multilevel inverter using MATLAB. The Zsource network is the energy storage/filtering element for the Z-source inverter.

The Z-source network provides a second-order filter and is more effective to suppress voltage and current ripples. Therefore, the inductor and capacitor requirement should be smaller than the traditional inverters. The presence of Total Harmonic Distortion (THD) is reduced up to $3.21 \%$ by using sine reference with $\mathrm{L}=160 \mu \mathrm{H}$ and $\mathrm{C}=1000 \mu \mathrm{F}$.

\section{References}

[1] K. Corzine and Y. Familiant, “ A New Cascaded Multilevel H Bridge Drive”, IEEE Transactions on Power Electronics, vol. 17, no. 1, (2002).

[2] F. Z. Peng, "Z Source Inverter", IEEE Transactions on Industrial Electronics, vol. 39, no. 2, pp. 504510, (2003).

[3] F. Z. Peng, X. Yuan, X. Fang and Z. Qian, "Z Source Inverter for Adjustable Speed Drives", IEEE Transactions on Power Electronics, vol. 1, no. 2, (2003), pp. 33-35.

[4] J. Wang, M. Shen, L. Chen, Z. Pan, E. O. Rivera and Y. Huang, "Z Source Inverter for Motor Drives", IEEE Transactions on Power Electronics, vol. 20, no. 4, (2005), pp. 857-863.

[5] F. Z. Peng, M. Shen and K. Hollan, "Application of Z Source Inverter for Traction Drive of Fuel CellBattery Hybrid Electric Vehicles", IEEE Transactions on Power Electronics, vol. 22, no. 3, (2007), pp. 
1054-1061.

[6] M. Shen and F. Z. Peng," Operation Modes and Characteristics of the Z source Inverter with Small Inductance or Low Power Factor", IEEE Transactions on Industrial Electronics, vol. 55, no. 1, (2008).

[7] R. Gupta, A. Ghosh and A. Joshi, "Switching Characterization of Cascaded Multilevel Inverter Controlled System", IEEE Transactions on Industrial Electronics, vol. 55, no. 3, (2008).

[8] Y. Tang, S. Xie, C. Zhang and Z. Xu, "Improved Z Source Inverter with Reduced Z-Source Capacitor Voltage Stress and Soft-Start Capability", IEEE Transactions on Power Electronics, vol. 24, no. 2, (2009), pp. 409-415.

[9] M. Malinowski, K. Gopakumar, J. Rodriguez and M. A. Pérez, "A Survey on Cascaded Multilevel inverters", IEEE Transactions on Industrial Electronics, vol. 57, no. 7, (2010).

[10] D. Cao, S. Jiang, X. Yu and F. Z. Peng, "Low-Cost Semi-Z-Source Inverter for Single-Phase Photovoltaic System", IEEE Transactions on Power Electronics, vol. 26, no. 12, (2011), pp. 3514-3523.

[11] M. R. Banaei, A. R. Dehghanzadeh, E. Salary, H. Khounjahan and R. A. Alizadeh, "Z Source Based Multilevel Inverter with Reduction of Switches”, IEEE Transactions on Power Electronics, vol. 5, no. 3, (2012), pp. 385-392.

[12] Minh-Khai Nguyen, Young-Chel Lim and Sung-Jun Park, "Improved Trans-Z-Source Inverter with Continuous Input Current and Boost Inversion Capability," IEEE Transactions on Power Electronics, Vol.28, No.10, pp.4500-4509, (2013).

[13] Sangeeta DebBarman and Tapas Roy, "Different Types of PWM Techniques analysis for Z Source Inverter", IOSR Journal of Electrical and Electronics Engineering, vol.9, no.3, (2014), pp.09-17.

[14] Mohit Tyagi, Atul Kushwaha, Shubra Goel, Amit kumar and Manoj Saini, "Modelling and simulation of PWM Based Z source Inverter Using MATLAB/Simulink", International Journal of Electrical and Electronics Engineers, vol.6, no.2, (2014).

[15] Ramalingam SEYEZHAI, Analysis of PWM Strategies for Z Source Cascaded Multilevel Inverter for Photovoltaic Applications", vol.77, no.2, (2015), pp.205-218.

[16] Fengjiang $\mathrm{Wu}$, Boyang $\mathrm{Li}$ and Jianddong Duan, "Calculation of switching loss and current total harmonics distortion of cascaded multilevel grid-connected inverter and Europe efficiency enhancement considering variation of DCsource power," IEEE Transactions on Power Electronics, Vol.9, No.2, pp.336-343, (2016).

[17] Yushan Liu, Haitham Abu-Rub and B.Ge, "Quasi- Z- Source Modular Cascaded Converter for HighPower Photovoltaic System," IEEE Transactions on PowerElectronics, pp.1226-1231, (2016).

[18] Yan Zhang, Jinjun Liu, Zhuo Dong and Yaoqin Jia, "Maximum Boost Control of Diode-assisted Buckboost Voltage Source Inverter with Minimum Switching Frequency", IEEE Transactions on Power Electronics,vol.pp,.99, (2016), pp.1-1.

[19] D.Sarala, "Design and Implementation of Improved Z Source Inverter Fed Induction Motor for Wind Applications", International Journal of Emerging Technology in Computer Science and Electronics, Vol.21, No.3, pp.735-738, (2016).

[20] Gnana Sambandam k, Akshay k. Rathore, Amarendra Edpuganti and Dipti Srinivasan, "Optimal Low Frequency Pulse Width Modulation of Current -Fed Five-Level Inverter for Solar Integration," IEEE Transactions onPower Electronics, 978-1-4673-9550-2/16, pp. 943-950, (2016).

[21] H. Mahmoudi, M. Aleenejad and R. Ahmadi, "Topology Exploration and Control of a Filter-Less ZSource Inverter", IEEE Transactions on Power Electronics, 978-1-5090-0261-0/16, (2016).

[22] M. Trablesi, H. Abu-Rub, and B. Ge, "1MW-Quasi Z Source based Multilevel PV Energy Conversion System," IEEE Transactions on Power Electronics, 978-1-4673-8075-1/16, (2016).

[23] S. Malathy and R. Ramaprabha, "A New Single Phase Multilevel Inverter Topology with Reduced Number of Switches", IEEE Transactions on Industrial Electronics, 978-1-4673-8262-5/16, (2016), pp. 139-144.

[24] R. V. Nair, S. A. Rahul, R. S. Karthik, A. Kshirsagar and K. Gopakumar, "Generation of High Number of Voltage Levels by Stacking Inverters of Lower Multilevel Structures with Low Voltage Devices for Drives", IEEE Transactions on Power Electronics, (2016), pp. 1-8.

[25] C. R. Balamurugan, S. P. Natarajan and T. S. Anandhi, "Single Phase Symmetrical Multilevel Inverter Design for Various Loads", Electrical and Electronics Engineering: An International Journal, vol. 5, no. 2, (2016), pp. 25-35. 